\title{
Effect of doping and sintering in structure and magnetic properties of the diluted magnetic semiconductor $\mathrm{ZnO}: \mathrm{Ni}$
}

\section{(Efeito da dopagem e sinterização na estrutura e propriedades magnéticas do semicondutor magnético diluído $\mathrm{ZnO}: \mathrm{Ni}$ )}

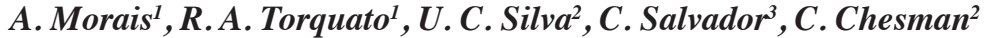 \\ ${ }^{1}$ Federal University of Paraíba, Department of Materials Engineering, João Pessoa, PB, Brazil \\ ${ }^{2}$ Federal University of Rio Grande do Norte, Department of Physics, Natal, RN, Brazil \\ ${ }^{3}$ Federal University of Paraíba, Department of Physics, João Pessoa, PB, Brazil
}

\begin{abstract}
This work aimed to study a sintered Ni-doped $\mathrm{ZnO}$ dilute magnetic semiconductor synthesized by means of a combustion reaction and to evaluate the effect of doping and sintering in the band gap and magnetic properties of the material. X-ray diffraction showed the formation of the $\mathrm{ZnO}$ semiconductor phase and also the formation of a second-phase characterized as a solid solution of nickelzinc oxide. The hysteresis curves showed the success in creating ferromagnetism with doping and the effect of sintering in the remanent magnetization and coercive field values, yet both systems were able to maintain its ferromagnetic behavior. The UV-vis analysis indicated the value of the band gap continued as a semiconductor material, although it has been narrowed. Scanning electron microscopy was used in a complementary way to evaluate the morphology and its effects on magnetic properties.
\end{abstract}

Keywords: dilute magnetic semiconductor, sintering, ferromagnetism, combustion reaction.

\section{Resumo}

Este trabalho teve o objetivo de estudar um semicondutor magnético diluído ZnO dopado com Ni sinterizado, sintetizado por meio de reação de combustão, e avaliar o efeito da dopagem e sinterização no gap e nas propriedades magnéticas do material. A difração de raios $X$ mostrou a formação da fase semicondutora $\mathrm{ZnO}$ e também formação de uma segunda fase caracterizada como solução sólida de óxido de níquel-zinco. As curvas de histerese evidenciaram o efeito da dopagem na criação do ferromagnetismo e o efeito da sinterização na queda nos valores de magnetização remanescente e campo coercitivo, porém ambos os sistemas foram capazes de manter seus comportamentos ferromagnéticos. A análise UV-vis indicou que o valor do gap continuou como o de um material semicondutor, embora tenha sido estreitado. Microscopia eletrônica de varredura foi usada de forma complementar na avaliação da morfologia e seus efeitos nas propriedades magnéticas.

Palavras-chave: semicondutor magnético diluído, sinterização, ferromagnetismo, reação de combustão.

\section{INTRODUCTION}

Diluted magnetic semiconductors (DMS) are materials in which transition metals or rare earth ions are doped in the crystalline lattice, giving rise to ferromagnetic properties in the doped semiconductor. The possibility of joining these properties attracted attention for a wide range of electrical, optical and magnetic applications in the area of spintronics, such as data storage [1], spin-LED [2], nonvolatile memories [3], and many others. Spintronics is based on controlling the spin of the electrons, by applying electrical fields or optical stimulus [4]. For this, materials with ferromagnetism and semiconducting properties are required. Since the most used semiconductors do not have suitable magnetic properties, it is necessary to introduce the ferromagnetism. The main way to obtain ferromagnetic semiconductors is doping with transition metal (TM) ions $(\mathrm{Fe}, \mathrm{Cr}, \mathrm{V}, \mathrm{Ni}$,

*arturdemorais32@gmail.com
$\mathrm{Mn}$ ) in semiconducting hosts, such as $\mathrm{TiO}_{2}$ [5], $\mathrm{ZnS}$ [6], and $\mathrm{ZnO}$ [7]. Wide band gap semiconductors are used for the production of DMS by many synthesis techniques and presenting ferromagnetism at room temperature [8]. Zinc oxide $(\mathrm{ZnO})$ is a semiconducting material with applications ranging from electronics to biomaterials and medical fields, has a wide energy gap between 3.2 and $3.4 \mathrm{eV}$ and can be easily produced by many techniques [9]. As a DMS, zinc oxide has been reported by numerous synthesis routes, showing ferromagnetism at or above room temperature.

A simple synthesis route to prepare ferromagnetic DMS $\mathrm{ZnO}$ is the combustion reaction [10, 11]. This process consists of a rapid and exothermic chemical reaction, useful in the production of many ceramic nanopowders. During the reaction, high temperatures can be achieved by the decomposition of a fuel-oxidizer mixture; this contributes to eliminate impurities and ensure crystallization of the products. The process can be controlled by changing parameters like heating rate, stoichiometry of reactants 
and volume of the container [12]. The calculations of fueloxidizer stoichiometry can be done with the method described in [13], taking into consideration the oxidation number of all reducing and oxidizing elements of the reactants. As almost every material requires some kind of treatment to reach its final use (e.g., to give form or mechanical strength), which can affect the final properties of the material, this work aims to sinter an already synthesized and studied Ni-doped $\mathrm{ZnO}$ by combustion reaction $[14,15]$, and to evaluate the effects of the heat-treatment in the crystalline structure, morphology and magnetic properties of the DMS.

\section{MATERIALS AND METHODS}

The reactants were zinc nitrate hexahydrate, $\mathrm{Zn}\left(\mathrm{NO}_{3}\right)_{2} \cdot 6 \mathrm{H}_{2} \mathrm{O}$, nickel nitrate hexahydrate, $\mathrm{Ni}\left(\mathrm{NO}_{3}\right)_{2} \cdot 6 \mathrm{H}_{2} \mathrm{O}$, and urea, $\mathrm{CO}\left(\mathrm{NH}_{2}\right)_{2}$, as fuel (all reagents from Vetec with $98 \%$ purity). The system formed was $\mathrm{Zn}_{1-\mathrm{x}} \mathrm{Ni}_{\mathrm{x}} \mathrm{O}$, with $\mathrm{x}$ being 0.08 and $0.15 \mathrm{~mol}$ of $\mathrm{Ni}$. The system formation reaction was:

$(1-\mathrm{x}) \mathrm{Zn}\left(\mathrm{NO}_{3}\right)_{2} \cdot 6 \mathrm{H}_{2} \mathrm{O}+\mathrm{xNi}\left(\mathrm{NO}_{3}\right)_{2} \cdot 6 \mathrm{H}_{2} \mathrm{O}+\mathrm{nCO}\left(\mathrm{NH}_{2}\right)_{2} \rightarrow$ $\mathrm{Zn}_{1-\mathrm{x}} \mathrm{Ni}_{\mathrm{x}} \mathrm{O}+$ gas $\left(\mathrm{N}_{2}, \mathrm{CO}_{2}, \mathrm{H}_{2} \mathrm{O}\right)$

The number of moles, $\mathrm{n}$, of fuel was determined based on the total valence of the oxidants and reducers [13]. The reaction was performed in a silica crucible, heated by an electric resistance at $500{ }^{\circ} \mathrm{C}$ until reached ignition. The reaction product was dried in a muffle furnace at $500{ }^{\circ} \mathrm{C}$ for $5 \mathrm{~min}$ and then de-agglomerated with a 325 -mesh $(45 \mu \mathrm{m})$ sieve. The powder was then pressed with a load of 2 ton for 1 $\mathrm{min}$, relieved and then pressed again with the same load and time, resulting in small pellets. The sintering was performed in a muffle furnace by heating at $10{ }^{\circ} \mathrm{C} / \mathrm{min}$, holding at $1000^{\circ} \mathrm{C}$ for $2 \mathrm{~h}$, and then cooled inside the furnace to room temperature. After that, the samples were characterized by the following methods. X-ray diffraction (XRD) was done with the Shimadzu XRD-6000 diffractometer, in the $2 \theta$ range of $30-75^{\circ}$, with $2 \%$ min scanning rate, $\mathrm{CuK \alpha}$ radiation (1.5406 ̊), $30 \mathrm{kV}$ voltage and $30 \mathrm{~mA}$ current. The hysteresis curves were obtained with vibrating sample magnetometry, VSM LakeShore mod. 7404. The hysteresis cycles were performed at $300 \mathrm{~K}$, with a maximum applied field of $7 \mathrm{k}$ Oe at a rate of $5 \mathrm{Oe} / \mathrm{s}$. The material band gap was studied using the UV-vis technique with Shimadzu UV2550 spectrophotometer (wavelength range of 200-900 nm). The morphology of the material was analyzed by scanning electron microscopy (SEM) with the LEO 1430 microscope.

\section{RESULTS AND DISCUSSION}

Fig. 1 shows the $\mathrm{X}$-ray diffraction patterns for undoped $\mathrm{ZnO}$ and $\mathrm{ZnO}: \mathrm{Ni}$ systems. The original $\mathrm{ZnO}$ wurtzite hexagonal structure (space group $\mathrm{P} 63 \mathrm{mc}$ ) was maintained for all studied concentrations. The peaks indicated by $\mathrm{Z}$ corresponded to zinc oxide $(\mathrm{ZnO})$ and all the reflection planes were the same as the wurtzite structure found in the literature (ICSD 01-079-0208). Additionally, characteristic peaks of the nickel-zinc oxide solid solution, indicated by $\mathrm{N}\left(\mathrm{Ni}_{6} \mathrm{Zn}_{4} \mathrm{O}\right.$, ICSD 01-075-0273), appeared in all Ni-doped systems, becoming stronger with the increase in $\mathrm{Ni}$ content. This solid solution is completely formed when $\mathrm{NiO}$ and $\mathrm{ZnO}$ mix is heated for $5 \mathrm{~h}$ at temperatures between 1000 and $1250{ }^{\circ} \mathrm{C}$ [16]. In this work, the samples were heated for only $2 \mathrm{~h}$, so the solid solution was expected not be completely formed, and $\mathrm{NiO}$ was expected to be present. With doping, the peaks positions of the wurtzite structure were slightly shifted to greater $2 \theta$, which characterize a decrease in the basal spacing of the respective diffraction planes. Table I shows the $2 \theta$ positions and the interplanar spacing $\mathrm{d}$ for the reflection plane (101), the most intense diffraction for the $\mathrm{ZnO}$ wurtzite structure. The values were taken directly from the XRD diffractograms. The decrease in $\mathrm{d}$ is explained by the substitution of $\mathrm{Zn}^{2+}$ for $\mathrm{Ni}^{2+}$ ions and their radii (ionic radius of 0.74 and $0.69 \AA$, respectively). This decrease in d, which also correlated to decrease in lattice parameters, indicated that the Ni ions were incorporated in the structure

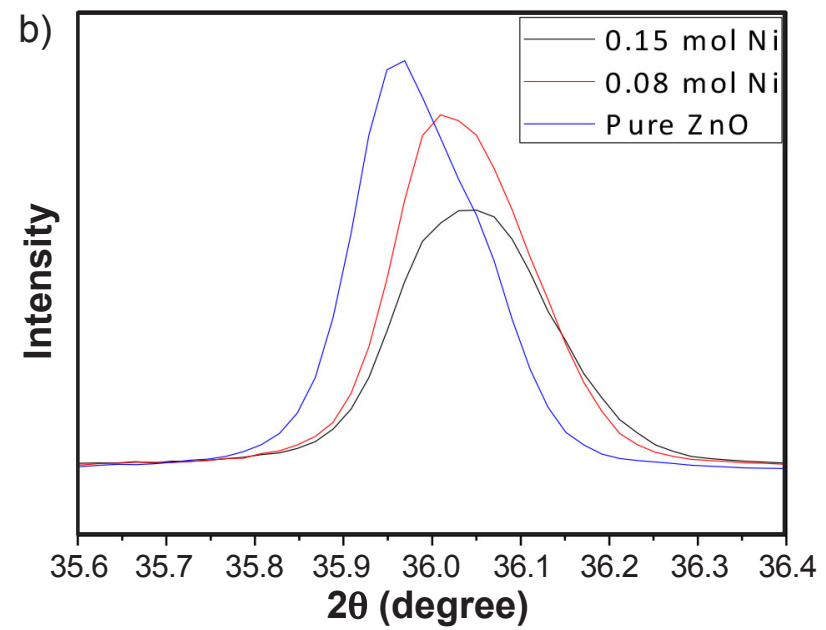

Figure 1: X-ray diffraction patterns of ZnO:Ni systems (a), and displacement of (101) plane of HCP structure (b). [Figura 1: Difratogramas de raios X dos sistemas ZnO:Ni (a) e deslocamento do plano (101) da estrutura HC (b).] 
Table I - $2 \theta$ position and interplanar spacing, $\mathrm{d}$, of diffraction plane (101).

[Tabela I - Posição $2 \theta$ e espaçamento interplanar, $d$, do plano de difração (101).]

\begin{tabular}{ccc}
\hline System & $2 \theta\left(^{\circ}\right)$ & $\mathrm{d}(\AA)$ \\
\hline ICSD 01-079-0208 & 36.1000 & 2.4861 \\
Pure ZnO & 35.9573 & 2.4956 \\
$0.08 \mathrm{~mol} \mathrm{Ni}$ & 36.0051 & 2.4924 \\
$0.15 \mathrm{~mol} \mathrm{Ni}$ & 36.0044 & 2.4925 \\
\hline
\end{tabular}

$[17,18]$. The formation of secondary phase can be explained by the difference in bond energy of $\mathrm{Ni}^{2+}-\mathrm{O}^{2-}$ and $\mathrm{Zn}^{2+} \mathrm{O}^{2-}$. The nickel-oxygen bond has higher energy, which means that more energy is required to $\mathrm{Ni}^{2+}$ ions enter the lattice and form the nickel-oxygen bond, when compared to zincoxygen bond. Hence, $\mathrm{Ni}^{2+}$ ions have higher stability relative to $\mathrm{Zn}^{2+}$ in $\mathrm{Zn}-\mathrm{O}$ structure, requiring more energy to induce crystallization in doped systems [19]. Considering this, it was concluded that the energy of the combustion reaction was not enough to complete the dilution of $\mathrm{Ni}$ ions into the $\mathrm{ZnO}$ lattice.

Figs. 2 and 3 show the magnetic hysteresis of pure $\mathrm{ZnO}$ and $\mathrm{ZnO}: \mathrm{Ni}$ systems. The cycle of the pure $\mathrm{ZnO}$ was characteristic of a diamagnetic material. In Table II the remanent magnetization $(\mathrm{Mr})$ and coercive field $(\mathrm{Hc})$ of both $\mathrm{ZnO}: \mathrm{Ni}$ systems in powder form and after sintering (inset in Fig. 3) are presented. Hysteresis curves were obtained at room temperature and showed that both sintered systems were capable to maintain the ferromagnetism after the heat treatment. The presence of $\mathrm{NiO} / \mathrm{Ni}_{6} \mathrm{Zn}_{4} \mathrm{O}$ phases negatively affected the magnetic moment of the material due to both oxides being antiferromagnetic [20]. With increased doping, the second-phase becomes more evident, so it was expected the magnetic moment to decrease. For the powder samples, this decrease only happened when the doping varied from 0.15 to $0.25 \mathrm{~mol}$ of Ni [14]. After sintering, the remanent magnetization $(\mathrm{Mr})$ also decreased when the doping was 0.15 mol. Hou et al. [18] discuss the decrease in magnetization based on $\mathrm{Ni}^{2+}-\mathrm{Ni}^{2+}$ bond distance. In lower concentrations, the $\mathrm{Ni}^{2+}-\mathrm{Ni}^{2+}$ distance is longer, resulting in weaker ferromagnetic interaction, hence, remanent and saturation magnetizations are expected to be lower. This interaction is strongest on the highest magnetization. With further increase in $\mathrm{Ni}$ doping, the $\mathrm{Ni}^{2+}-\mathrm{Ni}^{2+}$ distance decrease, resulting in an antiferromagnetic arrangement of

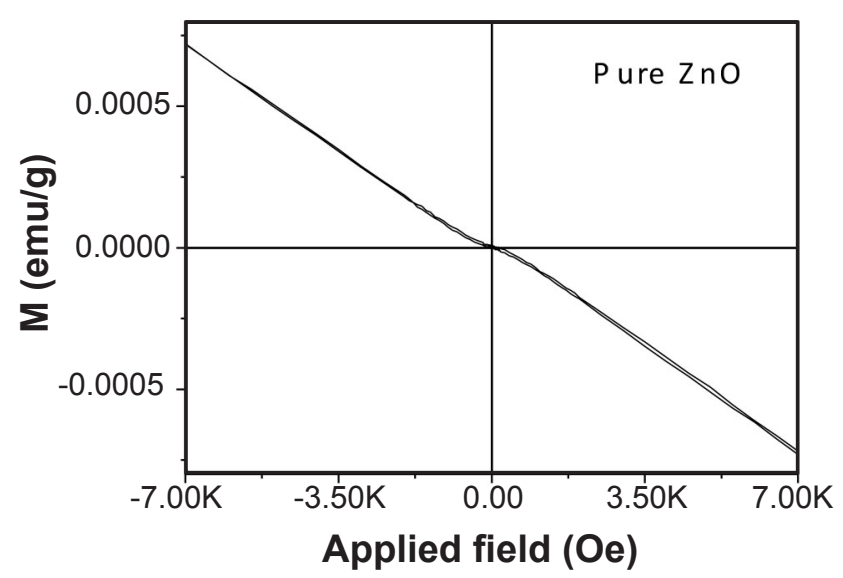

Figure 2: $\mathrm{ZnO}$ diamagnetic cycle.

[Figura 2: Ciclo diamagnético do ZnO.]

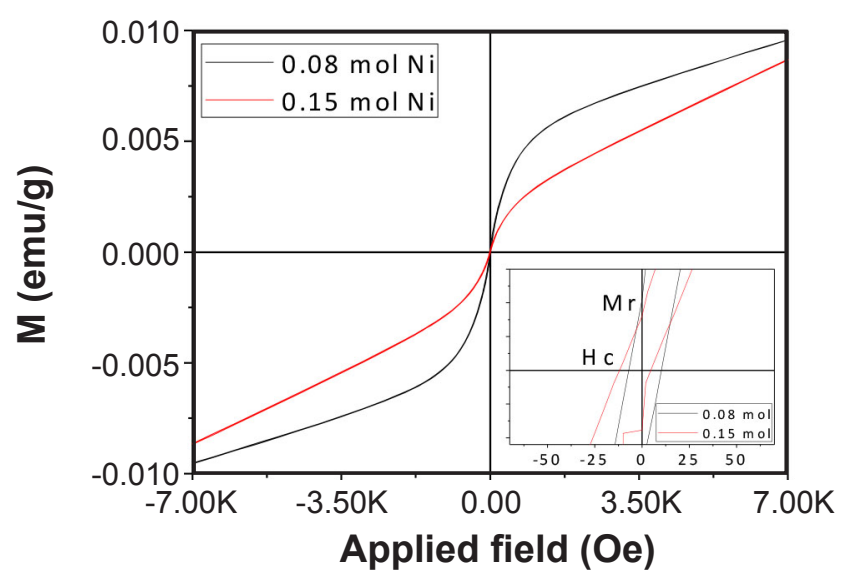

Figure 3: Magnetic hysteresis curves of $\mathrm{ZnO}$ :Ni systems.

[Figura 3: Curvas de histerese magnética dos sistemas ZnO:Ni.]

the Ni moments [18]. Another explanation for the lower magnetization is based on the morphology of the samples. Fig. 4 shows the SEM images of both sintered systems. It can be noted that the system with $0.15 \mathrm{~mol}$ of $\mathrm{Ni}$ had a denser structure and smaller particle size when compared to the system with $0.08 \mathrm{~mol}$ of $\mathrm{Ni}$. It is known that a material with fewer defects (like porosity), larger grains and a denser structure favors the displacement of the walls of magnetic domains (the walls can move more freely), with a smaller pinning region, making the coercive field $(\mathrm{Hc})$ and the remanent magnetization (Mr) smaller [21].

To determine the energetic gap of the material the Tauc method was used. In this method, the absorbance spectrum

Table II - Remanent magnetization (Mr) and coercive field (Hc) before and after sintering.

[Tabela II - Magnetização remanescente (Mr) e campo coercitivo (Hc) antes e após a sinterização.]

\begin{tabular}{|c|c|c|c|c|}
\hline \multirow[b]{2}{*}{ Mol of $\mathrm{Ni}$} & \multicolumn{2}{|c|}{ Powder } & \multicolumn{2}{|c|}{ Sintered } \\
\hline & 0.08 & 0.15 & 0.08 & 0.15 \\
\hline $\mathrm{Hc}(\mathrm{Oe})$ & $-161.13 \pm 0.02$ & $-174.74 \pm 0.06$ & $-8.14 \pm 0.14$ & $-12.89 \pm 0.03$ \\
\hline $\begin{array}{c}\mathrm{Mr} \\
(\mathrm{emu} / \mathrm{g})\end{array}$ & $0.15516 \pm 0.00014$ & $0.18192 \pm 0.00013$ & $(1.2979 \pm 0.0009) \times 10^{-4}$ & $(9.2411 \pm 0.0026) \times 10^{-5}$ \\
\hline
\end{tabular}



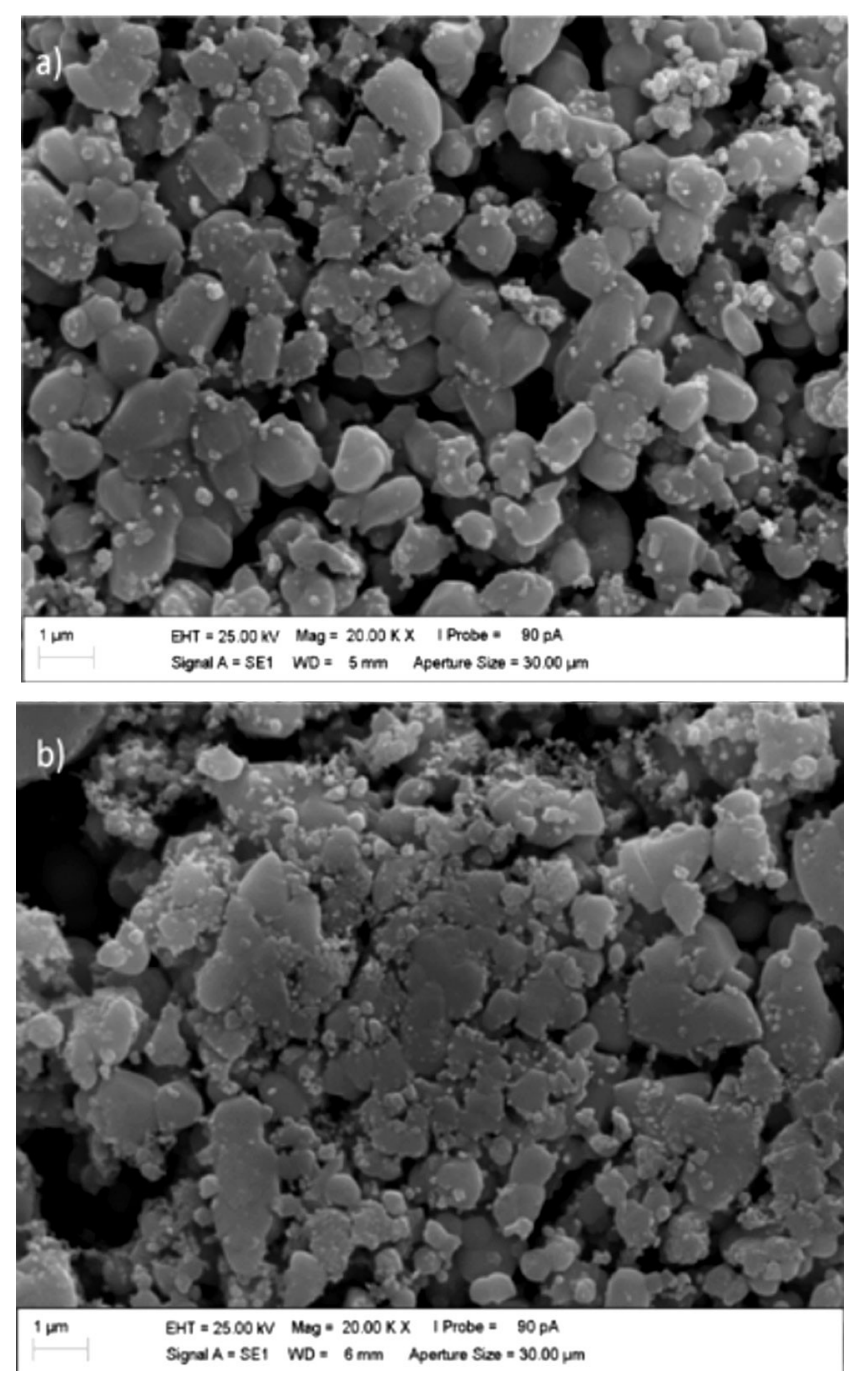

Figure 4: SEM micrographs of sintered systems: a) $0.08 \mathrm{~mol}$ of $\mathrm{Ni}$; and b) $0.15 \mathrm{~mol}$ of Ni.

[Figura 4: Micrografias de MEV dos sistemas sinterizados: a) 0,08 mol de Ni; e b) 0,15 mol de Ni.]

of the material was used to determine its absorption energy and to estimate the value of the electronic gap, given by:

$$
(\mathrm{h} v \cdot \mathrm{abs})^{\mathrm{n}}=\mathrm{A}\left(\mathrm{h} v-\mathrm{E}_{\mathrm{g}}\right)
$$

where: hv is the energy of the wavelength used in the UV-vis, given in electron-volt $(\mathrm{eV})$, abs is the absorbance obtained in UV-vis spectrum, Eg is the band gap and A is a proportionality parameter. The value of index $n$ is determined by the type of electronic transition of the studied material. For direct transitions, $\mathrm{n}$ is 2 ; for indirect transitions, $\mathrm{n}$ is $1 / 2$ [22]. $\mathrm{ZnO}$ has a direct transition, with a gap varying between 3.2 and $3.4 \mathrm{eV}$. Plotting the left side of Eq. B on the $y$-axis and the energy on the X-axis gave the graphs shown in Fig. 5 for pure $\mathrm{ZnO}$ and $\mathrm{Ni}$-doped samples. Extrapolating the linear regions until the $\mathrm{x}$-axis is the cutoff, and the term (hv.abs) ${ }^{2}=0$ (Eq. B). With this, the value corresponding to the intersection of the $\mathrm{x}$-axis and the extrapolated line gave the energy value that is the band gap of the material. This approach worked for pure
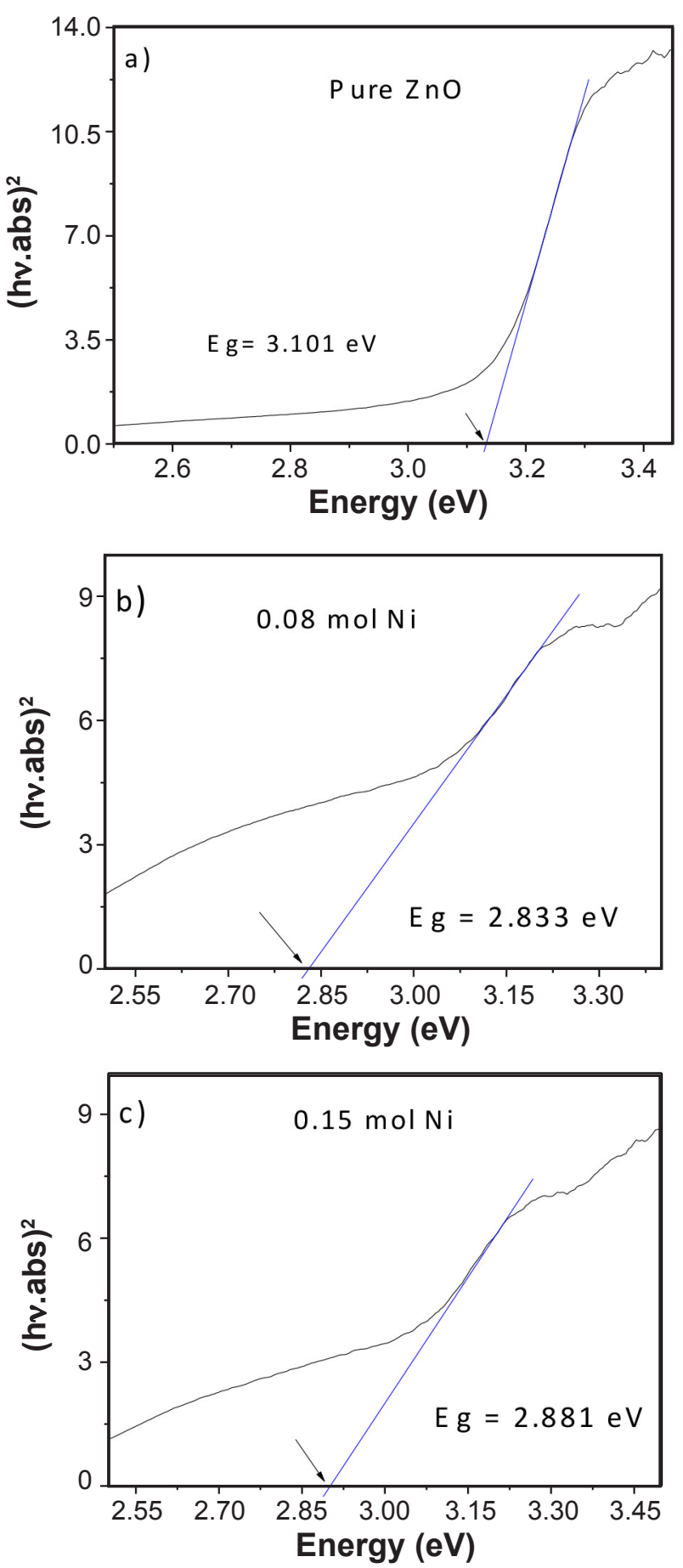

Figure 5: Tauc plot for band gap determination of: a) pure $\mathrm{ZnO}$; b) sample with $0.08 \mathrm{~mol}$ of $\mathrm{Ni}$; and c) sample with $0.15 \mathrm{~mol}$ of $\mathrm{Ni}$. [Figura 5: Gráfico de Tauc para determinação do band gap de: a) $\mathrm{ZnO}$ puro; b) amostra com 0,08 mol de $\mathrm{Ni}$; e c) amostra com 0,15 mol de Ni.]

$\mathrm{ZnO}$ and gave a value of about $3.101 \mathrm{eV}$ (Fig. 5a), which is close to that reported in the literature for the $\mathrm{ZnO}$ band gap. Table III lists the gaps values for the $\mathrm{ZnO}$ :Ni systems. The band gap for the doped samples was smaller when compared to pure $\mathrm{ZnO}$, meaning that the band gaps were redshifted. The cause for this redshift is attributed to sp-d exchange interactions of d-electrons from $\mathrm{Ni}^{2+}$ and band electrons [23, 
Table III - Values of band gap of $\mathrm{ZnO}$ :Ni systems.

[Tabela III - Valores do band gap dos sistemas ZnO:Ni.]

\begin{tabular}{cc}
\hline Mol of Ni & $\mathrm{Eg}(\mathrm{eV})$ \\
\hline 0.08 & $2.833 \pm 0.002$ \\
0.15 & $2.881 \pm 0.004$ \\
\hline
\end{tabular}

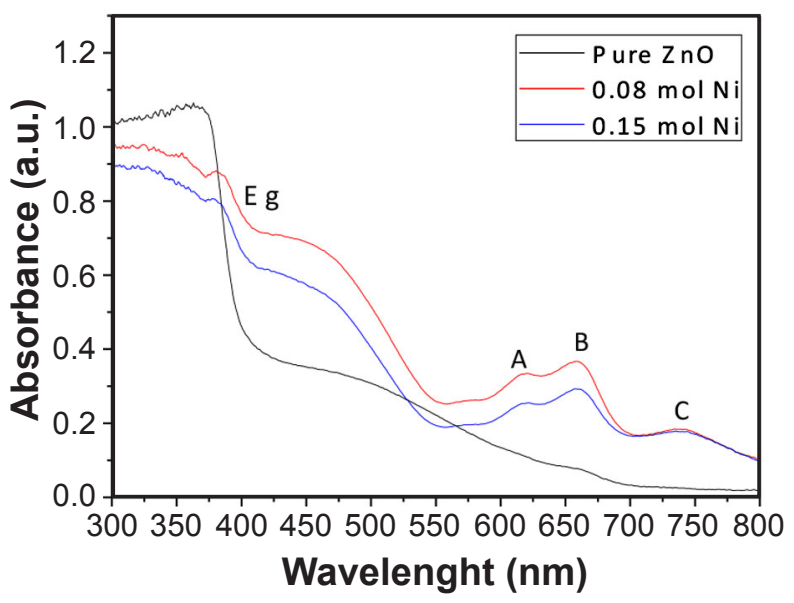

Figure 6: Absorbance spectra of pure $\mathrm{ZnO}$ and $\mathrm{ZnO}$ :Ni systems. [Figura 6: Espectros de absorbância do $\mathrm{ZnO}$ puro e sistemas $\mathrm{ZnO}: \mathrm{Ni}$.

24]. Fig. 6 shows the absorption spectra of pure and Ni-doped samples. The redshift of the band gap is evidenced in the main absorption, indicated by Eg. The absorptions designated as $\mathrm{A}, \mathrm{B}$ and $\mathrm{C}$ are specific transitions of $\mathrm{Ni}^{2+}$ ions in tetrahedral symmetry, which is the case when $\mathrm{Ni}$ ions substitute $\mathrm{Zn}$ in the lattice of $\mathrm{ZnO}$. This indicated that some of the $\mathrm{Ni}$ ions still remained incorporated after the sintering treatment [24-26].

\section{CONCLUSIONS}

The energy availability of the thermal treatment contributed to the increase of the content of second-phases (higher energy for diffusion of the $\mathrm{Ni}$ ions in the lattice), which in turn increased the antiferromagnetic characteristics of the systems, negatively affecting the desired ferromagnetism. The sintering process also contributed to a greater densification of the material, making it denser, and consequently, leaving the magnetic domains with freer movement. The UV-vis analysis suggested that both systems suffered a narrowing in the band gap and confirmed that $\mathrm{Ni}$ ions remained in the $\mathrm{ZnO}$ tetrahedral sites after the sintering treatment. The studied material was able to maintain the ferromagnetism and semiconductive properties. It is confirmed that even after a heat treatment at temperatures as high as $1000{ }^{\circ} \mathrm{C}$ the material can sustain the properties desired for a diluted magnetic semiconductor.

\section{ACKNOWLEDGMENT}

The authors are grateful for the financial support of the
CNPq Scientific Initiation Program (PIBIC).

\section{REFERENCES}

[1] M.N. Baibich, J.M. Broto, A. Fert, F. Nguyen Van Dau, F. Petroff, P. Eitenne, G. Creuzet, A. Friederich, A.J. Chazelas, Phys. Rev. Lett. 61, 21 (1988) 2472.

[2] R. Fiederling, M. Keim, G. Reuscher, W. Ossau, G. Schmidt, A. Waag, L.W. Molenkamp, Nature 402 (1999) 787.

[3] J. Zhu, Proc. IEEE 96, 11 (2008) 1786.

[4] S. Fusil, V. Garcia, A. Barthélémy, M. Bibes, Ann. Rev. Mat. Res. 44 (2014) 91.

[5] Y. Matsumoto, M. Murakami, T. Shono, T. Hasegawa, T. Fukumura, M. Kawasaki, P. Ahmet, T. Chikyow, S. Koshihara, H. Koinuma, Science 291 (2001) 854.

[6] W. Zhao, Z. Wei, L. Zhang, X. Wu, X. Wang, J. Jiang, J. Alloys Compd. 698 (2017) 754.

[7] T. Dietl, H. Ohno, F. Matsukura, Phy. Rev. B 63, 19 (2001) 195205.

[8] T. Dietl, H. Ohno, Rev. Mod. Phys. 86, 1 (2014) 187.

[9] R. Suryanarayanan, in: ZnO Nanocryst. Allied Mater., Ed. M. Rao, T. Okada, Springer, New Dheli (2014).

[10] R.A. Torquato, S.E. Shirsath, R.H.G.A. Kiminami, A.C.F.M. Costa, Ceram. Inter. 40 (2014) 6553.

[11] R.A. Torquato, S.E. Shirsath, R.H.G.A. Kiminami, A.C.F.M. Costa, Ceram. Inter. 44 (2018) 4126.

[12] R.H.G.A. Kiminami, A.C.F.M. Costa, M.R. Morelli, in: Handb. Nanoceram. Based Nanodevices, Taiwan (2009) 2 .

[13] S.R. Jain, K.C. Abiga, V.R.P. Verneker, Comb. Flam. 40 (1981) 71.

[14] A. Morais, R.A. Torquato, A.C.F.M. Costa, Rev. Eletr. Mater. Proc. 10, 2 (2015) 73.

[15] A. Morais, R.A. Torquato, A.C.F.M. Costa, Rev. Eletr. Mater. Proc. 12, 1 (2017) 26.

[16] H. Kedesdy, A. Drukalsky, J. Am. Chem. Soc. 76, 23 (1954) 5941.

[17] Z. Gu, C. Yuan, M. Lu, J. Wang, D. Wu, S. Zhang, S. Zhu, Y. Zhu, Y. Chen, J. App. Phys. 98 (2005) 53908.

[18] D. Hou, R. Zhao, Y. Wei, C. Zhen, C. Pan, G. Tang, Curr. App. Phys. 10 (2010) 124.

[19] S. Zhao, P. Li, Y. Wei, Powder Tech. 224 (2012) 390.

[20] P. Grange, H. Charcosset, P. Gallezot, P. Turlier, J. Vialle, J. Solid State Chem. 11, 1 (1974) 26.

[21] R.N. Faria, L.F.C.P. Lima, Introdução ao magnetismo dos materiais, Ed. Livrar. Fís., S. Paulo (2005) 63.

[22] M. Meinert, G.J. Reiss, Phy. Cond. Matter. 26, 11 (2014) 115503.

[23] S. Husain, F. Rahman, N. Ali, P.A. Alvi, J. Opt. Eng. 1, 1 (2013) 28.

[24] S. Deka, P.A. Joy, Chem. Mater. 17 (2005) 6507.

[25] P.V. Radovanovic, D.R. Gamelin, Phys. Rev. Lett. 91, 15 (2003) 157202.

[26] H.A. Weakliem, J. Chem. Phys. 36, 8 (1962) 2117.

(Rec. 26/03/2018, Rev. 07/05/2018, Ac. 05/07/2018) 